\title{
The effect of occupational exposure to mercury vapour on the fertility of female dental assistants
}

\author{
Andrew S Rowland, Donna Day Baird, Clarice R Weinberg, David L Shore, Carl M Shy, \\ Allen J Wilcox
}

\begin{abstract}
Exposure to mercury vapour or inorganic mercury compounds can impair fertility in laboratory animals. To study the effects of mercury vapour on fertility in women, eligibility questionnaires were sent to 7000 registered dental assistants in California. The final eligible sample of 418 women, who had become pregnant during the previous four years, were interviewed by telephone. Detailed information was collected on mercury handling practices and the number of menstrual cycles without contraception it had taken them to become pregnant. Dental assistants not working with amalgam served as unexposed controls. Women with high occupational exposure to mercury were less fertile than unexposed controls. The fecundability (probability of conception each menstrual cycle) of women who prepared 30 or more amalgams per week and who had five or more poor mercury hygiene factors was only $63 \%$ of that for unexposed women (95\% CI 42\%-96\%) after controlling for covariates. Women with low exposure were more fertile, however, than unexposed controls. Possible explanations for the $U$ shaped dose response and limitations of the exposure measure are discussed. Further investigation is needed that uses biological measures of mercury exposure.
\end{abstract}

(Occup Environ Med 1994;51:28-34)

In laboratory mice, rats, and hamsters, chronic exposure to inorganic mercury compounds disrupts the oestrous cycle, ${ }^{1-5}$ impedes follicular development, ${ }^{2}$ and impairs embryo implantation..$^{5}$ Only one study has examined the effects of mercury vapour on fertility, reporting lengthening of the oestrous cycle and reductions in the number of implantations in exposed rats, but no differences in the number of mated females that became pregnant. ${ }^{6}$

Little is known about the reproductive toxicity of mercury vapour in humans. Six studies, mostly conducted in Eastern Europe, have reported abnormalities of the menstrual cycle including painful menstruation and changes in bleeding patterns and menstrual cycle duration among workers exposed to mercury $^{7-12}$; two of these studies involved dental workers. ${ }^{10} 12$
Although mercury is poorly absorbed through the skin and gastrointestinal tract, mercury vapour is efficiently absorbed through the lung. ${ }^{13}$ The dissolved vapour remains in the blood long enough to cross the blood brain barrier where it is oxidised and eliminated only very slowly. ${ }^{14}$ Necropsy studies of occupationally exposed subjects have found high concentrations of mercury in the pituitary, thyroid, and brain 1516 and there is evidence that mercury persists in these tissues for many years. ${ }^{17}$ Whether the mercury that accumulates is biologically active and therefore able to interfere with endocrine or reproductive function is not known. Three small studies ${ }^{18-20}$ have looked at pituitary and thyroid function in subjects with chronic exposure to mercury vapour. The results were ambiguous; pituitary and thyroid function seemed clinically normal but there were differences in prolactin or sex hormone binding globulin concentrations that might suggest an underlying effect.

The evidence that mercury accumulates in the brain, pituitary, and thyroid, that it disrupts ovulation in animals, and that women exposed to mercury experience abnormal menstrual cycles suggests that mercury vapour may impair fertility in humans.

To date there have been no epidemiological studies of the effect of mercury vapour on human female fertility. The purpose of this study was to investigate such effects among female dental assistants. Mercury is a principal component of the silver amalgam used to fill teeth. In most dental offices it is the job of the dental assistant to prepare the amalgam. Consequently most dental assistants are chronically exposed to low concentrations of mercury vapour unless they work in specialties like orthodontics or oral surgery and do not handle amalgam. As a group, dental assistants have urinary mercury concentrations higher than the general population or other dental personnel, ${ }^{21}$ and cases of mercury poisoning have occasionally been reported..$^{22}$ Most dental assistants, however, have urinary mercury concentrations well below $50 \mu \mathrm{mg} / \mathrm{g}$ creatinine, ${ }^{21}$ the recommended exposure limit proposed by the World Health Organisation. ${ }^{23}$

In this study, subfertility was assessed retrospectively by collecting information on time to pregnancy, ${ }^{24}$ defined as the number of menstrual cycles women took to become pregnant, adjusted for their frequency of unprotected sexual intercourse. This retrospective method of studying fertility ${ }^{24}$ has 
been used to investigate the effects of such factors as oral contraceptive use ${ }^{25}$ and-cigarette smoking ${ }^{2627}$ and may be a sensitive screening tool for evaluating occupational exposures as well.

\section{Methods}

\section{STUDY PARTICIPANTS}

This study was conducted in two phases. Firstly, 7000 dental assistants aged 18-39 years were randomly selected from the dental assistant registry maintained by the California Department of Consumer Affairs and sent a four page screening questionnaire. The questionnaire data were used to determine eligibility for the second phase of study, which involved:a detailed telephone interview.

Of the 7000 dental assistants, eight were dead or living out of the country. Of those remaining, 4856 (69\%) completed screening information, 232 (3\%) could not be traced, 204 (3\%) acknowledged receipt but declined to participate, and 1704 (24\%) did not respond. There were five eligibility criteria for further participation: (1) women had to have been pregnant within the past four years; (2) their most recent pregnancy could not have been due to failure of birth control; (3) they must have been married at the time they discontinued contraception; (4) they must have worked full time (at least 30 hours a week) in a dental profession during the six months before they began to have unprotected intercourse; and (5) they must not have changed their exposure to mercury during this six month interval (that is, if a woman changed jobs, both jobs had to involve mercury exposure or both jobs had to be free of mercury exposure). Four hundred and fifty nine women (9\%) met these requirements. A further 101 women $(2 \%)$ completed the mail questionnaire but could not be classified because of missing data on the screening questionnaire and 108 women (2\%) were potentially eligible but did not include a correct telephone number on their form so they could not be included in the telephone interview. The most common reasons for exclusion were never having been pregnant $(35 \%)$ and not having been pregnant in the past four years $(27 \%)$.

Women screened and found to be eligible for the study were asked to complete a telephone interview. Of the 459 women eligible for the study, 418 (91\%) completed the full interview. Those not completing interviews either refused ( $n=36)$, could not be interviewed because of language problems $(n=2)$, or could not be contacted before data collection for the study ended $(n=3)$. The 418 completed interviews constitute the data for this study.

\section{DATA COLLECTION}

Data were collected between June 1987 and May 1988. Telephone interviews, averaging 38 minutes in duration, were aimed at obtaining detailed information about reproductive and contraceptive history and occu- pational exposures. The interviews were conducted by trained female interviewers who were not informed of the specific hypotheses of the study.

Time to pregnancy was ascertained by establishing the interval before the most recent pregnancy during which each woman was having unprotected sexual intercourse. ${ }^{24}$ The date at the beginning of this interval was designated the "reference date." The number of menstrual cycles to pregnancy was calculated by taking the time between the reference date and the date of the last normal menstrual cycle, dividing by usual menstrual cycle duration, and adding one cycle (to account for the cycle in which conception occurred). Any menstrual cycles within this interval in which no intercourse occurred were subtracted (affecting time to pregnancy for six women). Menstrual cycles during which birth control was used sporadically were added as half cycles and rounded down to the nearest whole cycle (affecting time to pregnancy for 23 women). Although women were required to have had a pregnancy during the past four years, some had begun trying to become pregnant many years before. The reference dates for women in this study ranged from January 1974 to October 1987.

Data were collected on occupational exposure to nitrous oxide, $x$ rays, sterilising agents, and methyl methacrylate, a plastic compound used in composite resins and dental prostheses. Women also provided information on demographic, medical, reproductive, and lifestyle factors as of the reference date.

\section{EXPOSURE ASSESSMENT}

Many researchers have reported a relation between the number of amalgams prepared and urinary or blood mercury concentrations, ${ }^{28-33}$ but others have not. ${ }^{34-40}$ An explanation for this discrepancy may be that the variability depends on the way that mercury is handled in the dental environment, not simply the amount of mercury used. ${ }^{41}$

Industrial hygiene surveys of dental offices have identified office characteristics and mercury handling practices that are likely to increase exposure to mercury vapour ${ }^{22}{ }^{41-47}$; detailed recommendations on the proper handling of mercury that incorporate this information have been published. ${ }^{41}{ }^{46}$ 48-51 We used these recommendations to identify mercury hygiene factors in the job held at the reference date that were likely to increase exposure to mercury (table 1 ). We estimated a woman's exposure to mercury vapour both by the number of amalgams she reported preparing each week (a measure of her potential exposure) and by the number of poor mercury hygiene factors in her job (a measure of her level of personal protection).

\section{ANALYTICAL APPROACH}

Time to pregnancy data were analysed with multivariate survivorship models to estimate the independent association of each factor of 
Table 1 Poor hygiene factors included in the mercury hygiene score and their frequency among 307 women who worked with amalgam

\begin{tabular}{|c|c|c|c|c|}
\hline Poor hygiene factor & No & (\%) & Comment & References \\
\hline 1 Hand contact with mercury & 68 & (23) & $\begin{array}{l}\text { Mixing mercury with mortar and pestle or expressing excess } \\
\text { mercury through cheese cloth. Old technologies which } \\
\text { increase potential for spills. Skin contamination likely. }\end{array}$ & 41 \\
\hline $\begin{array}{l}2 \text { Not using precapsulated } \\
\text { amalgam or not closing precapsulated } \\
\text { amalgam before disposal }\end{array}$ & 227 & (74) & $\begin{array}{l}\text { Precapsulated amalgam reduces need for handling large } \\
\text { amounts of free mercury and decreases potential for spills. } \\
\text { Disposable capsules can become source of contamination if } \\
\text { they are not reclosed before disposal. }\end{array}$ & 2837 \\
\hline $\begin{array}{l}3 \text { Not wearing gloves when } \\
\text { preparing amalgam }\end{array}$ & 184 & (49) & $\begin{array}{l}\text { Increases probability of skin absorption. Increases risk of } \\
\text { contaminating hands, clothes, and work area. }\end{array}$ & 22 \\
\hline 4 No cover on amalgamator & 97 & (32) & $\begin{array}{l}\text { Amalgamator is machine that shakes amalgam capsules at } \\
\text { high speed. Cover helps contain contamination. }\end{array}$ & 44 \\
\hline 5 Carpet in operating area & 252 & (82) & $\begin{array}{l}\text { Reservoir for spills. Vacuuming carpet with household } \\
\text { vacuum heats mercury and distributes it around room. } \\
\text { Vacuum can become seriously contaminated itself. }\end{array}$ & 4766 \\
\hline 6 Eating in operating area or laboratory & 205 & (67) & $\begin{array}{l}\text { Increases risk of gastrointestinal absorption of mercury. } \\
\text { General poor hygiene practice. }\end{array}$ & 41 \\
\hline 7 History of spills in office & 59 & (19) & $\begin{array}{l}\text { Refers to large spills of containers of free mercury. } \\
\text { Spills can contaminate an office for years. }\end{array}$ & 2236 \\
\hline 8 Improper disposal of mercury waste & 105 & (34) & $\begin{array}{l}\text { Disposing scrap amalgam down sink, in rubbish, or storing it } \\
\text { dry creates an ongoing source of mercury contamination. }\end{array}$ & 3944 \\
\hline
\end{tabular}

interest with fecundability, the probability of conception in any given menstrual cycle. ${ }^{24} 52$ Because the number of cycles to conception is a discrete time variable and many women conceive in their first or second cycle, the usual Cox proportional hazards model $^{53}$ is invalidated by numerous "ties". Instead, a discrete time analogue is used. ${ }^{52}$ This model assumes the exposure and covariates have multiplicative effects on the cycle specific conception rates. The baseline conception rate is allowed to be different for each cycle. The analysis is based on cycle by cycle successes and failures of the women for up to 13 menstrual cycles. This censoring at 13 cycles (about one year) was done to exclude possible effects of medical treatment for infertility, which typically begins only after one year of trying. The coefficients from this model can be used to calculate a fecundability ratio (analogous to a risk ratio or hazard ratio). The fecundability ratio estimates the ratio of the per cycle conception rate for the exposed compared to the unexposed subjects, adjusted for other covariates included in the model. For example, if the exposed women have a fecundability ratio of $0 \cdot 5$, this would suggest that exposed women are half as likely as unexposed women to conceive in any given cycle.

Statistical models were fitted by maximum like-lihood with the Generalised Linear Interactive Modelling (GLIM) software. ${ }^{54}$ The fits of nested models were compared by likelihood ratio statistics. All $p$ values given are two-sided.

Mercury exposure was examined by cross classifying number of amalgams and number of poor hygiene factors into categories based on the distribution of the data $(0-14,15-29$, and $\geqslant 30$ for weekly number of amalgams, and $0-3,4$, and 5-8 for the number of poor mercury hygiene factors). Other cutoff points were considered but the effects were not sensitive to the boundaries used. Mercury was initially examined with only number of amalgams prepared each week and then with a model that incorporated both number of amalgams and number of poor hygiene factors.
Lifetime occupational exposure to mercury was crudely estimated with employment history; data from the mail questionnaire were used to calculate cumulative lifetime number of amalgams prepared before the reference date. Non-occupational mercury exposure was ascertained from data on weekly fish consumption and number of amalgam surfaces in the women's own mouth at the reference date.

Other variables that might affect fecundability were examined in preliminary analyses. Non-occupational exposures of potential importance were considered as of the reference date-namely, age, race, family income, exercise, Quetelet's index (weight/height ${ }^{2}$ ), alcohol, fish consumption, number of amalgam surfaces, recreational drug use, smoking, douching, history of using an intrauterine device, age at menarche, history of pelvic inflammatory disease, frequency of intercourse, lifetime number of sexual partners, and recent oral contraceptive use. Other occupational exposures examined were nitrous oxide, $x$ rays, methyl methacrylate, ethylene oxide (gas sterilisation), use of a chemiclave (heated chemical sterilising system containing formaldehyde), and cold sterilant use. Variables such as gravidity were not entered as potential confounders because they may have been caused, in part, by the exposure under study. ${ }^{55}$ Variables were entered in the model as dichotomous, as continuous, and as multilevel categorical variables to evaluate their relation to fecundability. With the exception of age, race, and history of pelvic inflammatory disease, variables not significantly related to fecundability were dropped. Two way interactions of fertility related covariates and exposure to mercury were tested in the final multivariate model.

A linear term for year the pregnancy attempt began was included in our statistical models to control for bias that could have been introduced by trends over calendar time in the opportunity for mercury exposure. ${ }^{56}$ Time trends may induce a spurious association between individual hygiene factors and time to pregnancy. Because we sampled on a 
woman's most recent pregnancy, women who took a long time to become pregnant (several years) had a greater opportunity to be exposed to poor mercury hygiene practices that were more common in the past than women who became pregnant more quickly and therefore, on average, more recently.

\section{Results}

Dental assistants who worked with amalgam ( $n=296)$ were similar to women who did not work with amalgam $(n=111)$ for age, family income, history of pelvic inflammatory disease, oral contraceptive use, frequency of intercourse, and cigarette smoking (table 2). There was a higher percentage of non-whites among dental assistants exposed to mercury $(20 \% v 8 \%)$ and a slightly higher percentage of women who had worked as a dental assistant for less than six years $(30 \% v 23 \%)$. The most striking differences between the two groups involved their patterns of occupational exposure; women who prepared amalgam were seven times more likely to administer $\mathbf{5 0}$ or more $x$ rays per week $(55 \% v 8 \%)$ and were over four times as likely to work with nitrous oxide $(60 \% v 13 \%)$. Also $97 \%$ of the exposed women worked with cold sterilants $v$ $86 \%$ of the unexposed women.

The variables significantly related to time to pregnancy were: recent oral contraceptive

Table 2 Characteristics of the study population by exposure state

\begin{tabular}{|c|c|c|}
\hline Variable & $\begin{array}{l}\text { Unexposed } \\
\text { No }(\%)\end{array}$ & $\begin{array}{l}\text { Amalgam users } \\
\text { No }(\%)\end{array}$ \\
\hline Total study population & $111(100)$ & $296(100)$ \\
\hline$>30$ years & $17(15)$ & $35(11)$ \\
\hline $\begin{array}{l}\text { Race } \\
\text { Non-white }\end{array}$ & $9(8)$ & $60(20)$ \\
\hline $\begin{array}{l}\text { Family income } \\
<\$ 30000 / \text { year } \\
\$ 30000-\$ 45000 \\
>\$ 45000\end{array}$ & $\begin{array}{l}44(40) \\
39(36) \\
26(24)\end{array}$ & $\begin{array}{r}116(38) \\
128(42) \\
58(19)\end{array}$ \\
\hline $\begin{array}{l}\text { Total years working as dental assistan } \\
\begin{array}{l}1-5 \\
6-10 \\
\geqslant 11\end{array}\end{array}$ & $\begin{array}{l}26(23) \\
57(51) \\
28(25)\end{array}$ & $\begin{array}{r}93(30) \\
146(48) \\
68(22)\end{array}$ \\
\hline $\begin{array}{l}\text { History of pelvic } \\
\text { inflammatory disease }\end{array}$ & $3(3)$ & $6(2)$ \\
\hline $\begin{array}{l}\text { Lifetime number of sexual partners } \\
>5 \text { partners } \\
\text { Oral contraceptive use }\end{array}$ & $19(18)$ & $39(13)$ \\
\hline Immediately before reference date & $21(19)$ & $61(20)$ \\
\hline $\begin{array}{l}\text { Frequency of intercourse } \\
1 \text { or less per week } \\
2-3 \text { times per week } \\
\geqslant 4 \text { times per week }\end{array}$ & $\begin{array}{c}17(16) \\
54(51) \\
36(34)\end{array}$ & $\begin{array}{r}49(16) \\
145(48) \\
109(36)\end{array}$ \\
\hline $\begin{array}{l}\text { Cigarettes smoked per day } \\
0 \\
1-19 \\
\geqslant 20\end{array}$ & $\begin{array}{c}103(93) \\
6(5) \\
2(2)\end{array}$ & $\begin{array}{c}279(91) \\
27(9) \\
3(1)\end{array}$ \\
\hline $\begin{array}{l}\text { Nitrous oxide exposure } \\
\text { Unexposed } \\
\text { Low exposed } \\
\text { High exposed } t\end{array}$ & $\begin{array}{c}94(87) \\
12(11) \\
2(2)\end{array}$ & $\begin{array}{c}120(41) \\
159(54) \\
17(6)\end{array}$ \\
\hline $\begin{array}{l}x \text { Rays administered } \\
0 \text { per week } \\
1-50 \text { per week } \\
>50 \text { per week }\end{array}$ & $\begin{array}{c}53(48) \\
48(44) \\
9(8)\end{array}$ & $\begin{array}{c}3(1) \\
134(44) \\
170(55)\end{array}$ \\
\hline $\begin{array}{l}\text { Cold sterilant use } \\
0 \text { per week } \\
1-50 \text { per week } \\
>50 \text { per week }\end{array}$ & $\begin{array}{l}15(14) \\
59(53) \\
37(33)\end{array}$ & $\begin{array}{r}10(3) \\
217(71) \\
79(26)\end{array}$ \\
\hline
\end{tabular}

Table 3 Adjusted fecundability ratios * by number of amalgams prepared per week

\begin{tabular}{lrll}
\hline $\begin{array}{l}\text { No of amalgams } \\
\text { per week }\end{array}$ & No & $\begin{array}{l}\text { Fecundability } \\
\text { ratio }\end{array}$ & 95\% CI \\
\hline 0 & 100 & 1.00 & \\
$1-14$ & 76 & 1.33 & $(1 \cdot 03-1 \cdot 72)$ \\
$15-29$ & 79 & 1.25 & $(0 \cdot 97-1 \cdot 63)$ \\
$30-59$ & 82 & 0.90 & $(0 \cdot 68-1 \cdot 19)$ \\
$60+$ & 36 & 0.87 & $(0 \cdot 58-1 \cdot 29)$ \\
\hline
\end{tabular}

*Adjusted for recent oral contraceptive use, age, race, smoking, pelvic inflammatory disease, number of sex partners, frequency of intercourse, unscavenged nitrous oxide, and year the pregnancy attempt began.

use, number of previous sexual partners $(<6$, $\geqslant 6$ ), frequency of intercourse, exposure to unscavenged nitrous oxide ( $<5$ hours/week, $\geqslant 5$ hours/week), number of cigarettes smoked per day, and year the pregnancy attempt began. Age, race, and history of pelvic inflammatory disease were also included in all statistical models to improve interpretation of the results. Estimates of effect for these covariates other than mercury have been reported previously. ${ }^{57}$ After covariate adjustment, the estimated fecundability of the women varied according to the number of amalgams they prepared each week ( $p<0.03)$; women who prepared fewer than 30 amalgams per week had higher fecundability than unexposed women, but women who prepared 30 or more amalgams per week tended to have lower fecundability than the unexposed subjects (table 3 ).

Incorporating mercury hygiene factors added important information to our statistical models and suggested that considerable heterogeneity existed within groups of women preparing the same number of amalgams. When the model with number of amalgams prepared each week was augmented with mercury hygiene factors and the interaction between mercury hygiene factors and number of amalgams prepared per week, the improvement in fit (for the nine parameter model shown in table 4) was statistically significant (likelihood ratio $\chi^{2} 6 \mathrm{df}=12.9, \mathrm{p}<0.05$ based on a comparison with a three parameter model involving only the amalgam categories of table 4). The fit of the full model was also significantly better than a model with the same covariates but excluding mercury (without any of the nine parameters

Table 4 Adjusted fecundability ratios * by number of amalgams prepared per week and number of poor mercury hygiene factors

\begin{tabular}{llll}
\hline $\begin{array}{l}\text { No of } \\
\text { amalgams } \\
\text { per week }\end{array}$ & \multicolumn{4}{l}{ No of poor hygiene factors } \\
\cline { 2 - 4 } & $0-3$ & 4 & $5-8$ \\
\hline 0 & $1.0(\mathrm{n}=100)$ & - & - \\
$1-14$ & $1.39(\mathrm{n}=32)$ & $1.22(\mathrm{n}=20)$ & $1.53(\mathrm{n}=24)$ \\
$15-29$ & $(1.01-1.92)$ & $(0.81-1.83)$ & $(1.03-2 \cdot 25)$ \\
& $1.42(\mathrm{n}=33)$ & $1 \cdot 17(\mathrm{n}=23)$ & $1.14(\mathrm{n}=23)$ \\
$\geqslant 30$ & $(1.05-1.92)$ & $(0.79-1.75)$ & $(0.73-1.77)$ \\
& $1.32(\mathrm{n}=43)$ & $0.81(\mathrm{n}=37)$ & $0.63(\mathrm{n}=38)$ \\
& $(0.97-1.80)$ & $(0.55-1.18)$ & $(0.42-0.96)$ \\
\hline
\end{tabular}
^Adjusted for recent oral contraceptive use, age, race, smok-
ing, pelvic inflammatory disease, partners, frequency of intering, pelvic inflammatory disease, partners, frequency of intercourse, unscavenged nitrous oxide, and year the pregnancy
attempt began. $95 \%$ CI in parentheses under the ratio; $\mathrm{n}=$ number of women. 
involving categories of poor mercury hygiene factors or number of amalgams; $\chi^{2} 9$ $\mathrm{df}=24.5, \mathrm{p}<0.01$ ).

Table 4 shows the results from the fully developed model and presents adjusted fecundability ratios both by number of amalgams and number of poor hygiene factors. Women who prepared fewer than 30 amalgams a week had better fecundability than the unexposed population regardless of their mercury hygiene (fecundability ratios ranged from $1 \cdot 14$ to $1 \cdot 53$ ). Similarly, women who prepared 30 or more amalgams a week with the best mercury hygiene also had better fecundability than the unexposed women. Those with 30 or more amalgams a week and four or more poor mercury hygiene factors had lower fecundability, however, than the unexposed women. The thirty eight women in our highest exposure group (women preparing 30 or more amalgams a week and five or more poor hygiene factors) had the lowest fecundability (fecundability ratio = 0.63 ; 95\% CI 0.42-0.96) after adjustment for covariates.

If only exposed women are considered, there are gradients in the fecundability ratio for both the number of amalgams prepared per week (within work practice category) and the number of poor hygiene factors (within amalgam category) that suggest a doseresponse in the higher exposure categories. Among women who prepared 30 or more amalgams per week, there was a steep gradient in fecundability ratio by the number of poor hygiene factors $(1.3,0.8$, and 0.6$)$. There was a similar but less steep gradient among women preparing 15-29 amalgams per week $(1 \cdot 4,1 \cdot 2$, and $1 \cdot 1)$. Among women

Table 5 Mean number of menstrual cycles to conception and proportion of women taking more than 13 menstrual cycles to conceive by number of amalgams and number of poor mercury hygiene factors

\begin{tabular}{llll}
\hline \multirow{2}{*}{$\begin{array}{l}\text { No of amalgams } \\
\text { per week }\end{array}$} & \multicolumn{3}{l}{ No of poor hygiene factors } \\
\cline { 2 - 4 } & $0-3$ & 4 & $5-8$ \\
\hline 0 & $6 \cdot 4$ & & \\
& $12 / 100(12)$ & & \\
$1-14$ & $3 \cdot 0$ & $5 \cdot 1$ & 3.5 \\
$15-29$ & $0 / 32(0)$ & $1 / 20(5)$ & $0 / 24(0)$ \\
& $3 \cdot 0$ & $6 \cdot 5$ & $6 \cdot 8$ \\
& $1 / 33(3)$ & $4 / 23(17)$ & $5 / 23(22)$ \\
& $6 \cdot 0$ & $13 \cdot 9(5)$ & $15 \cdot 1$ \\
& $2 / 43(5)$ & $9 / 37(24)$ & $14 / 38(37)$ \\
\hline
\end{tabular}

Proportion of women in each cell taking more than 13 cycles expressed as a fraction (\%).

Table 6 Unadjusted fecundability ratios by number of amalgams and number of poor mercury hygiene factors

\begin{tabular}{|c|c|c|c|}
\hline \multirow{2}{*}{$\begin{array}{l}\text { No of } \\
\text { amalgams } \\
\text { per week }\end{array}$} & \multicolumn{3}{|c|}{ No of poor hygiene factors } \\
\hline & $0-3$ & 4 & $5-8$ \\
\hline 0 & $1.00(n=100)$ & - & - \\
\hline $1-14$ & $\begin{array}{l}1.49(\mathrm{n}=32) \\
(1.06-2.09)\end{array}$ & $\begin{array}{l}1.17(n=20) \\
(0.76-1.80)\end{array}$ & $1.31(n=24)$ \\
\hline $15-29$ & $\begin{array}{l}1 \cdot 54(\mathrm{n}=33) \\
(1 \cdot 10-2 \cdot 15)\end{array}$ & $\begin{array}{l}0.98(n=23) \\
(0.64-1.52)\end{array}$ & $0.87(\mathrm{n}=23)$ \\
\hline$\geqslant 30$ & $\begin{array}{l}1.31(\mathrm{n}=43) \\
(0.95-1.80)\end{array}$ & $\begin{array}{l}0.70(n=37) \\
(0.48-1.04)\end{array}$ & $\begin{array}{l}0.49(\mathrm{n}=38) \\
(0.32-0.75)\end{array}$ \\
\hline
\end{tabular}

$95 \% \mathrm{CI}$ in parentheses under the ratio; $\mathrm{n}=$ number of women. preparing the fewest amalgams there was no gradient by number of poor hygiene factors $(1.4,1.2,1.5)$. Similarly, there was a steep gradient by number of amalgams among women with the highest number of poor hygiene factors $(1.5,1.1,0.6)$, a weaker gradient among women in the middle group for hygiene factors $(1.2,1.2$, and 0.8$)$, but no gradient among women with the best hygiene factors $(1 \cdot 4,1 \cdot 4,1 \cdot 3)$.

The same dose-response pattern was seen in unadjusted measures of mean number of cycles to conception and the proportion of women taking more than 13 menstrual cycles (about one year) to become pregnant (table 5 ). The unadjusted fecundability ratios (table 6) showed roughly the same picture.

\section{Discussion}

Women with occupational exposure to mercury vapour (30 or more amalgams per week and four or more poor mercury hygiene factors) showed evidence of reduced fertility in this dataset. This is consistent with animal experiments and with reports of menstrual cycle problems among women with occupational exposure to mercury.

Our study relied on detailed descriptions of the work environment and mercury handling practices to infer amounts of exposure to mercury vapour based on previous research that has correlated urinary mercury concentrations or air monitoring results with mercury hygiene factors in the dental office (table 1). Among groups of women preparing the same number of amalgams we found differences in fecundability based on the dental assistant's reported number of poor mercury hygiene factors. This suggests that detailed occupational hygiene scales may be useful in other questionnaire studies of occupational disease because occupational groups with roughly the same potential for exposure often contain subjects whose actual exposures are quite different depending on their particular work environment and their work practices within that environment.

Although most dental offices have mercury vapour levels well below the OSHA permissible exposure limit of $50 \mu \mathrm{mg} / \mathrm{m}^{3}$, most studies have identified a group of offices with exposures above this level 225859 (about $10 \%$ to $20 \%$ of the offices surveyed). Twenty per cent of the women in our final sample reported preparing more than 30 amalgams per week with four or more poor hygiene factors. Even though we do not have biological measures of exposure, it seems likely that many of these women may have worked in offices with exposures approaching or exceeding the permissible exposure limit.

An important limitation of using data on hygiene factors to estimate exposure is that it often will be correlated with other occupational or personal lifestyle exposures. Although we evaluated other potential occupational exposures of concern such as use of nitrous oxide, $x$ rays, and sterilants as well as many lifestyle factors such as smoking, alco- 
hol, and recreational drug use, our finding of reduced fertility among women in our high mercury group could reflect other exposures found among women working in offices with poor hygiene and many amalgams.

Our exposure measure was based on exposure around the time each woman began her attempt to become pregnant, not cumulative lifetime occupational exposure. To assess the effects of past exposure, we used data from the screening questionnaire to construct a cumulative index of lifetime number of amalgams placed before the reference date. There was no relation between cumulative lifetime number of amalgams placed and fertility although this number was only a crude approximation of lifetime mercury exposure.

Unexposed women in our study had lower fertility than low exposed women (but better fertility than women in the two highest exposure groups.) This pattern was consistently present within the univariate (tables 5 and 6) and the multivariate data (tables 3 and 4) but is not one that we can readily explain. One hypothesis we considered was that our "unexposed" group may have had other unmeasured occupational exposures that reduced their fertility. The unexposed group included both women who worked in orthodontic offices and a group of women from various other subspecialties who did not work with amalgam. Both groups showed similar lower fertility than the low exposed group, indicating that it was not due to some exposure exclusive to orthodontic offices, the largest subgroup within the unexposed women. More detailed data on other exposures incurred by dental assistants who do not work with amalgam would be needed to explore this further. We also explored the possibility that the low exposed group were primarily administrative personnel who were different in other respects. Examining such variables as family income, gravidity, and seniority in the job, however, did not support this hypothesis. In fact, the study sample is restricted to one occupational group and demographically is quite homogeneous.

Another possible explanation for the $U$ shaped dose response is that it may have been influenced by different participation rates between the unexposed and the low exposed. Unexposed women may have been less likely to participate. Among those who did, a disproportionate number may have been disposed to cooperate, in part, because they were having fertility problems. Unfortunately, we were unable to explore this possibility further because the dental assistant registry included no data on the subspecialty of the offices in which women worked.

Finally, a biological explanation for higher fertility among the low exposed women is possible. Predosing animals with low amounts of cadmium or mercury reduces the toxicity of subsequent, higher exposures to these metals. ${ }^{6061}$ The underlying mechanism for these results is believed to involve induction of metallothionein, an intracellular pro- tein that binds and detoxifies metals. ${ }^{62-64}$ Experimental evidence also suggests that metallothionein may offer some protection against low level exposures to $x$ rays, free radicals, and alkylating agents. ${ }^{65}$ Further research is needed before the plausibility of this hypothesis can be adequately addressed.

We found reduced fertility among the two groups of women in our study with the highest estimated exposure to mercury vapour, and a suggestion of dose response trends in the fecundability ratios among the two highest categories of number of amalgams and the two highest categories of poor hygiene factors. This provides limited evidence that mercury vapour may impair female fertility and justification for more intensive epidemiological study of the reproductive toxicity of mercury. In the interim, dental personnel would be wise to err on the side of caution and implement the already well established guidelines for good mercury hygiene. ${ }^{48} 51$

This research was jointly funded by the National Institute of Environmental Health Sciences and the National Institute for Dental Research. Joy Pierce directed the field work of the study. Pat Bullard, Rosanna Coover, Susan Currie, Kathy Holland, Catherine Houghton, and Molly Talent adminisHolland, Catherine Houghton, and Molly Talent administered the detailed telephone interviews. Laura Fischler super-
vised the preparation of data for analysis. Sherry Gates, D Robert McConnaughey, and N Beth Ragan provided computer assistance. Doug Bell, Ann Coker, Esther John, Maureen Hatch, Linda Kaste, Ruth Little, Dale Sandler, David Savitz, Sherry Selevan, John Stamm, H A Tyroler, and Elizabeth Whelan provided critical feedback that was important in the development of the study and the manuscript.

1 Lach $\mathrm{H}$, Srebro $\mathrm{Z}$. The oestrous cycle of mice during lead and mercury poisoning. Acta Biologica Cracoviensia Series Zoologica 1972;15:121-30. 2 Lamperti AA, Printz RH. Effects of mercuric chloride on
the reproductive cycle of the female hamster. Biol Reprod 1973;8:378-87.

3 Lamperti AA, Printz RH. Localization, accumulation, and toxic effects of mercuric chloride on the reproductive axis of the female hamster. Biol Reprod 1974;11:180-6.

4 Watanabe T, Shimada T, Endo A. Effects of mercury compounds on ovulation and meiotic and mitotic chromosomes in female golden hamsters. Teratology 1982; 25:381-4.

5 Kajiwara $\mathbf{Y}$, Inouye $M$. Inhibition of implantation caused by methylmercury and mercuric chloride in mouse 541-6.

6 Baranski B, Szymczyk I. Effects of mercury vapors upon reproductive function of the female white rat. Medycyna Pracy 1973;24:249-61.

7 Goncharuk GA. Problems relating to the occupational hygiene for women employed in mercury production. Gigiena Truda i Professional'nyze Zabolevaniya 1977;5: 17-20.

8 Panova $Z$, Dimitrov G. The ovarian function in women with occupational exposure to metallic mercury. Akusherstvo i Ginekologiya 1974;13:29-34.

9 Mikhailova LM, Kobyets GP, Lyubomudrov VE, Braga GF. The influence of occupational factors on diseases of the female reproductive organs. Pediatriya Akusherstvo Ginekologiya 1971;33:56-8.

10 Marinova G, Chakarova O, Kaneva YA. A study of reproductive function of women working with mercury. Problem na Akusherstvoto $i$ Ginekologiyata 1973;1:75-7.

11 DeRosis F, Anastasio SP, Selvaggi L, Beltrame A, Moriani G. Female reproductive health in two lamp factories: effects of exposure to inorganic mercury vapour tories: effects of exposure to inorganic mercury vapd
and stress factors. Br $\mathcal{F}$ Ind Med 1985;42:488-94.

12 Sikorski R, Juszkiewicz T, Paszkowski T, SzprengierJuszkiewicz $T$. Women in dental surgeries: reproductive hazzards in occupational exposure to metallic mercury hazards in occupational exposure to metalli

13 Clarkson TW, Cramer J, Sivulka DJ, Smith R. Mercury health effects update: health issue assessment EPA-600/8-84 $019 F$. Research Triangle Park, NC: US EPA, 1984

14 Clarkson TW. Mercury. Fournal of the American College of Toxicology 1989;8:1291-5.

15 Nylander M, Weiner J. Mercury and selenium concentrations and their interrelations in organs from dental staff and the general population. $B r \mathcal{F}$ Ind Med 1991;48: 729-34.

16 Kosta L, Byrne AR, Zelenko V. Correlation between 
selenium and mercury in man following exposure to inorganic mercury. Nature 1975;254:238-9.

17 Cavanaugh JB Long term persistence of mercury in the brain. Br f Ind Med 1988;45:649-51.

18 Langworth S, Rojdmark S, Akesson A. Normal pituitary hormone response to thyrotrophin releasing hormone in dental personnel exposed to mercury. Swed Dent $\mathcal{f}$ 1990;14:101-3.

19 Erfurth EM, Schutz A, Nilsson A, Barregard L, Skerfving S. Normal pituitary hormone response to thyrotrophin and gonadotrophin releasing hormones in subjects exposed to elemental mercury vapour. $\mathrm{Br} \mathcal{F}$ Ind $\mathrm{Med}$ 1990;47:639-44.

20 McGregor AJ, Mason HJ. Occupational mercury vapour exposure and testicular, pituitary, and thyroid endocrine function. Human and Experimental Toxicology 1991;10: 199-203.

21 Kelman GR. Urinary mercury excretion in dental personnel. Br f Ind Med 1978;35:262-5.

22 Smart ER. The hazards of mercury in dentistry. Reviews on Environmental Health 1985;5:59-86.

23 World Health Organisation. Recommended health-based limits in occupational exposure to heary metals. Geneva: its in occupational exposure to heavy metals. Geneva:
World Health Organisation, 1980 . WHO technical World Health 0

24 Baird DD, Wilcox AJ, Weinberg CR. Using time to pregnancy to study environmental exposures. $A m$ f Epidemiol 1986;124:470-80.

25 Linn S, Schoenbaum SC, Monson RR, Rosner B, Ryan $\mathrm{KJ}$. Delay in conception for former 'pill' users. $¥ A M A$ 1982;247:629-32.

26 Howe G, Westhoff C, Vessey M, Yeates D. Effects of age, cigarette smoking, and other factors on fertility: findings in a large prospective study. $B M 71985 ; 290: 1697-700$.

27 Baird DD, Wilcox AJ. Cigarette smoking associated with delayed conception. $\mathcal{F A M A} 1985 ; 253: 2979-83$.

28 Naleway C, Muller T, Sakaguichi R, Ayer WA, Mitchell E, Hefferren JJ. Urinary mercury levels in U.S. dentists E, Hefferren JJ. Urinary mercury levels in U.S. dentists 1975-1983: a review of the health assessment program.
fournal of the American Dental Association 1985; Fournal of

29 Herber RFM, DeGee AJ, Wibowo AAE. Exposure of dentists and assistants to mercury: mercury levels in urine and hair related to conditions of practice. Community Dentistry and Oral Epidemiology 1988;16:153-8.

30 Jokstad A. Mercury excretion and occupational exposure of dental personnel. Community Dentistry and Oral Epidemiology 1990;18:143-8.

31 Joselow MM, Goldwater LJ, Alvarez A, Herndon J. Absorption and excretion of mercury in man xv. occupational exposure among dentists. Archives of Environmental Health 1968;17:39-43.

32 Langan DC, Fan PL, Koos AA. The use of mercury in dentistry: a critical review of the recent literature. fournal of the American Dental Association 1987;115: fournal $867-80$.

33 Battistone GC, Hefferren JJ, Miller RA, Cutright DE. Mercury: its relation to the dentist's health and dental practice characteristics. Fournal of the American Dental Association 1976;92:1182-8

34 Brady JA, Gemmiti-Nunn D, Polan AK, Mitchell D, Weil R, Vianna NJ. The relationship of dental practice characteristics to blood mercury levels. New York State Dental fournal 1980:46:420; 422-4.

35 Moller-Madsen B, Hansen JC, Kragstrup J. Mercury concentrations in blood from Danish dentists. Scand $\mathcal{F}$ Dent Res 1988;96:56-9.

36 Nilsson B, Nilsson B. Mercury in dental practice II: urinary mercury excretion in dental personnel. Swed Dent $\mathcal{f}$

37 Nixon GS, Whittle CA, Woodfin A. Mercury levels in dental surgeries and dental personnel. Br Dent $f$ 1981; 151:149-54.

38 Harris D, Nicols JJ, Stark R, Hill K. The dental working environment and the risk of mercury exposure. Fournal of the American Dental Association 1978;97:811-5.

39 Skuba A. Survey for mercury vapor in Manitoba dental offices summer 1983. Can Dent Assoc 7 1984;7:517-22.

40 Skare I, Bergstrom T, Engqvist A, Weiner J. Mercury exposure of different origins among dentists and dental nurses. Scand $\mathcal{F}$ Work Environ Health 1990;16:340-7.

41 Buchwald H. Exposure of dental workers to mercury. Am Ind Hyg Assoc $\mathcal{F}$ 1972;33:492-502.

42 Brune D, Hensten-Pettersen A, Beltesbrekke H. Exposure to mercury and silver during removal of amalgam to mercury and silver during remo

43 Brune D, Beltesbrekke H. Mercury vapor levels in the dental laboratory. $\mathcal{F}$ Dent Res 1978;86:300-2

44 Jones DW, Sutow EJ, Milne EL. Survey of mercury vapour in dental offices in Atlantic Canada. Can Dent Assoc F 1983;6:378-94.

45 Richards JM, Warren PJ. Mercury vapour released during the removal of old amalgam restorations. Br Dent $\mathcal{f}$ 1985;159:231-2.

46 Schneider $M$. An environmental study of mercury contamination in dental offices. Fournal of the American Dental Association 1974;89:1092-8.

47 Votaw AL, Zey J. Vacuuming a mercury-contaminated dental office may be hazardous to your health. Dental dental office may be haze

48 FDI Working Group. Recommendations on dental mercury hygiene: revision of FDI technical report no. 7 cury hygiene: revision of FDI technical repc

49 Jones DE. Mercury: a review of the literature. Br Dent $\mathcal{F}$ 1981;151:145-8.

50 Littner MM, Kaffe I, Tamse A. Occupational hazards in the dental office and their control II. measures for controlling mercury intoxication. Quintessence International 1983;2:221-4

51 Council on Dental Materials I and Equipment. Recommendations in dental mercury hygiene. Fournal of the American Dental Association 1983;109:617-9.

52 Weinberg CR, Wilcox AJ, Baird DD. Reduced fecundability in women with prenatal exposure to cigarette ability in women with prenatal exposure

53 Cox DR. Regression models and life tables (with discussion). Fournal of the Royal Statistical Society B 1972;34: $187-220$

54 Baker RJ, Nelder JA. The GLIM system, release 3, manual. Oxford: Numerical Algorithms Group.

55 Weinberg CR. Toward a clearer definition of confounding. Am $\mathcal{F}$ Epidemiol 1993;137:1-8.

56 Weinberg CR, Baird DD, Rowland AS. Pitfalls inherent in retrospective time-to-event studies: the example of time to preonancy. Statistics in medicine 1993 (in press).

57 Rowland AS, Baird D, Weinberg CR, Shore DI, Shy CM, Wilcox AJ. Reduced fertility among women employed as dental assistants exposed to high levels of nitrous oxide. N Engl ₹Med 1992;327:993-7.

58 Brown D. Detection of mercury vapour in the dental surgery: an assessment of disposable monitoring discs. Br Dent f 1983;155:237-40

59 Smith DC, Lewis DW. Study calls for dental office investigations. Ontario Dentist 1987;64:21-6.

60 Waalkes MP, Goering PL. Metallothionein and other cadmium-binding proteins: recent developments. Chemical Research in Toxicology 1990;3:281-8.

61 Yoshikawa $\mathrm{H}$, Ohta $\mathrm{H}$. Interaction of metals and metallothionein. In: Foulkes EC, ed. Developments in toxicology and environmental science, vol 9: Biological roles of metallothionein. New York: Elsevier/North-Holland, 1982:11-25.

62 Lee YH, Shaikh ZA, Tohyama C. Urinary metallothionein and tissue metal levels of rats injected with cadmium, mercury, lead, copper, or zinc. Toxicology 1983; 27:337-45.

63 Nordberg GF. Modulation of metal toxicity by metallothionein. Biological Trace Element Research 1989;21:131-5.

64 Liu J, Kershaw WC, Klaassen CD. The protective effect of metallothionein on the toxicity of various metals in rat primary hepatocyte culture. Toxicology and Applied Pharmacology 1991;107:27-34.

65 Templeton DM, Cherian MG. Toxicological significance of metallothionein. Methods in Enzymology 1991;205: $11-24$

66 Roydhouse RH, Ferg MRF, Knox RP. Mercury in dental offices: survey in Vancouver, B.C. Fournal of the Canadian Dental Association 1985;2:156-8. 